\title{
Empirical Study: Cognitive Behavior Therapy (CBT) And Resilience of Prisoners before Being Released
}

\author{
Alief Budiyono ${ }^{1}$ \\ ${ }^{1}$ Corresponding author, \\ Fakultas Dakwah IAIN Purwokerto \\ Anwar Sutoyo ${ }^{3}$ \\ ${ }^{3}$ Doctoral Program Universitas Negeri Semarang \\ Kampus Sekaran Gunung Pati Semarang, Indonesia
}

\begin{abstract}
The aims of study were determine resilience's level of prisoners before being released in Class II A's Prison at Purwokerto; to find out the effectiveness of the Cognitive Behavior Therapy (CBT) technique to increase the resilience of prisoners before being released in Class II A's Prison at Purwokerto. This research was experimental study, while the type of experiment used is a type of pretest-posttest control group design experiment, an experiment that compares an effect on an experimental group that will be subject to treatment with a control group that is not subject to the dependent variable. The number of respondents were 20 prisoners. The results showed that the CBT technique could increase the resilience of prisoners before they were released in Class II A's Prison at Purwokerto. This was evidenced by analysis of the description which states that an increase in prisoner resilience from the beginning per test before treatment and after treatment (treatment). The effectiveness of the CBT technique has been proven to increase the resilience of prisoners to an increase after receiving treatment with the CBT technique. Significant improvement was seen from paired sample test $t$ and $N$ gain test showed that the hypothesis was accepted. The conclusion was CBT techniques are effective in increasing prisoners to be released in Class II A's Prison at Purwokerto.
\end{abstract}

Keywords:- effectiveness, prisoners, resilience, Cognitive Behavior Therapy $(C B T)$ and techniques.

\section{INTRODUCTION}

The condition of a prisoner is often deteriorated and bad because life in detention is filled with a lot of pressure, including psychological pressure, as well as the amount of detention capacity that is not in accordance with the number of prisoners and also the limited means of activity are very minimal. This will affect the emotions, feelings, thoughts, self-control, and self-concept of an inmate while serving time in detention. Feelings of anxiety, depression and the desire to commit suicide sometimes appear in prisoners (the results of an interview with a prisoner in Purwokerto prison). The desire of prisoners to commit suicide as stated (Müller, 2015) due to syndrome while living in detention.

\author{
DYB Sugiharto ${ }^{2}$ \\ ${ }^{2}$ Doctoral Program Universitas Negeri Semarang \\ Kampus Sekaran Gunung Pati Semarang, Indonesia \\ Maman Rachman ${ }^{4}$ \\ ${ }^{4}$ Doctoral Program Universitas Negeri Semarang \\ Kampus Sekaran Gunungpati Semarang, Indonesia
}

While serving their sentences, some prisoners have realized that what happened to them is only a trial of life, not as a result of the mistakes they have made. They believe that life in the world must face tests including life tests in detention. Those who realize this always see that this world is a prison or a place full of trials and torments for believers. With this they always prepare themselves by always being grateful, patient, and leaning on Allah swt. (Al-Qarni, 2006). After serving his sentence, a prisoner will return to the middle of the family or community. The problem faced by prisoners before their sentence ends is usually the emergence of concerns related to the role he will play after being released from detention. Concerns related to the role that had been left behind were new problems for prisoners before they were released. They should feel happy once their prison term is finished, but there are some prisoners who feel worried or anxious after approaching the free period (Kartono 2011; Utari, 2011; Henning 2011; Shienkfield 2010).

Prisoners who will be released from detention must have the ability to rise from a situation that is also badly needed by a prisoner. Prisoners really need the ability to become resilient individuals. Resilient person is a person who can rise from the worst situation that happened to him. So that resilience is needed by prisoners, especially for those whose sentence will end. Resilience according to Revich (2002) said a individual's ability for adaption and overcome all problems or events that befall individuals in their lives.

A prisoner is in dire need of resilience in him. A resilient inmate can be described as always having a plan he will do once he gets out of detention. The plan includes starting a new life with family or community, undergoing activities that have been passed unencumbered. So that by having high resilience a prisoner can carry out his developmental duties again after leaving prison. In general, resilience will lead to positive patterns of adaptation of individuals after dealing with risks or problems. Resilience is an idea that is based on the dynamic ability of individuals to survive or rise from adversity experienced by individuals (Utami and Avin, 2017). Meanwhile, according to (Revich, 2002) resilience is an effort made by individuals to adapt and rise again in facing life problems and all situations that squeeze their lives. According to (Dong et al., 2013) resilience is a measure of 
individual emotional endurance and can be increased by social interaction in a community consisting of individuals with relatively the same problems. Furthermore (Dong et al., 2013) said that aspects of resilience needed by individuals to always be resilient individuals include: having flexibility to overcome changes and challenges, the existence of family support and social environment, the influence of spirituality, and having a life oriented on purpose. These four aspects can later shape individuals into resilient individuals. Especially in the aspect of spirituality, in Class II A's Prison in Purwokerto facilities related to places of worship such as mosques, churches and temples are provided for prisoners to support religious activities.

Resilience is really needed by a prisoner in order to be able to survive and develop his abilities during serving time and become a provision in the time of release later. However, it is not uncommon to find someone's resilience in dealing with various problems that have befallen life as less than optimal. Individuals tend to surrender to the conditions that happen to them or even will experience various obstacles in living a good life obstacles or social, mental or physical disorders. The pattern of resilience of every human being has its uses.

The aims of study were determine resilience's level of inmates before being released in Class II A's Prison at Purwokerto; to find out the effectiveness of the Cognitive Behavior Therapy (CBT) technique to increase the resilience of prisoners before being released in Class II A's Prison at Purwokerto

\section{LITERATURE REVIEW}

\section{$>$ Cognitive Behavior Therapy (CBT)}

Simon Fraser University (2007) said CBT is a psychological treatment that discusses interactions between mindset, feeling and behavior that refer to the intervention group. CBT in psychological dysfunction is related to learning mechanisms and information processing. CBT is based on the basic assumption that emotional disorders are managed by cognitive factors, and psychological handling causes changes in cognitive and behavioral restructuring such as exposure, experimentation, exercise and skills.) (Beck and Emery in Taylor, 2006).

CBT in individuals who experience problems or disorders that differ in form and application where CBT is focused on changing behavior to reduce symptoms and improve the function of people affected (Roth, Eng, Heimberg in Taylor, 2006). The purpose of CBT is to teach clients to replace distorted thinking and cognitive assessments that are more realistic and adaptive.

There are three levels in the CBT model, among others Core beliefs or schemas are a 'belief' or 'trust' for yourself and the world around you. It is learned by humans from the beginning of life and is influenced by childhood experience and looks absolute. Core beliefs themselves are known for their cognitive triads, namely the self, the future, and the world. Functional assumptions are more rigid, because they are rules of life that are adapted and taught by the outside environment. Some rules look surreal and maladaptive to some people, but are useful and hold on to others. Automatic thoughts themselves are involuntary of the thoughts that are activated in certain situations. When depressed, for example automatic thoughts focus on things related to badness such as failure, and so on (Padesky and Mooney, 2012).

The CBT model is used as a work concept to understand one's mental state or find out a problem in a person. The process of putting idiosyncratic experiences to certain individuals. CBT aims to teach clients as subjects and objects in the therapeutic treatment itself. Clients become 'main counselors' by helping them understand several ways of thinking and acting and helping them with tools in changing their behavior. The main key to CBT is to create an empiricist collaborative environment and people who support the focus of the problem. This CBT needs to produce results in the form of the ability of clients to think effectively about problems and improve their ability to manage the problem. Therefore, CBT needs to be carried out in 5 steps namely 'SMART', specific (measurable), measurable, achievable, realistic and time-limited.

\section{$>$ Resilience}

Revich (2002) explains resilience as ability from individual to adapt a problem in his life and have a trauma experience. Resilience according to (Suwarjo, 2008) is the ability of individuals to overcome and deal with and respond positively to unpleasant conditions and conditions that are impossible to avoid, and utilize these unpleasant conditions to strengthen themselves so that they are able to change these conditions into something that is reasonable to overcome. Siebert (in Yuniardi, 2009) explains that resilience in individuals is very important because resilient individuals know how to restore mentality from adversity or misery and turn it into something better or positive, even compared to the previous situation. Pratiwi (2018) said that resilience will enable individuals to be able to come up with adaptive behavioral responses to new conditions and live life more optimistically, positively and productively.

According to Connor and Davidson (2003), resilience develop amid the difficulties being experienced by individuals. Luthans, Youssef and Avolio (in Octaryani et al., 2017) explained recilience was a invidual capacity to recover failure, or even events experienced by individuals whether it is a positive event, things that have progressed, and responsibility becomes more increase again. Smith et al., (2008) said resilience as resitance's individual for develop for recover stresser in life.

Resilience generally leads to positive patterns of adaptation of individuals during or after facing difficulties or risks in living life. Resilience is an idea that refers to the for dinamyc system to survive (Masten, 2007). Likewise, the opinion of Grotberg (1995) define resilience was a universal capacitiy for aperson, community and group to prevent and minimize af adversity. 
Based on several understandings, resilience is an attempt of a counselee, both individuals and groups to rise and move towards more productive life situations, and be able to build self-awareness as a perfect human being, and be able to overcome psychological problems that interfere with the development of his soul.

\section{$>$ Cognitive Behavior Therapy $(C B T)$ dan Resiliensi}

Suwarjo (2008) said that resilience is the ability of individuals to overcome and deal with and respond positively to unpleasant conditions and conditions that are impossible to avoid, and utilize these unpleasant conditions to strengthen themselves so that they are able to change these conditions into something that is reasonable to overcome. Siebert (in Yuniardi, 2009) explains that resilience in individuals is very important because resilient individuals know how to restore mentality from adversity or misery and turn it into something better or positive, even compared to the previous situation. Pratiwi (2018) said that resilience will enable individuals to be able to come up with adaptive behavioral responses to new conditions and live life more optimistically, positively and productively.

According to Connor and Davidson (2003) stated resilience as measurement for individuals who are considered successful. Luthans, Youssef and Avolio (in Octaryani et al., 2017) explained that resilience is recover from adversity, conflict, failure, or even events experienced by individuals whether it is a positive event, things that have progressed, and responsibility becomes more increase again.

Resilience generally leads to positive patterns of adaptation of individuals during or after facing difficulties or risks in living life.

Based on several understandings, resilience is an attempt of a counselee, both individuals and groups to rise and move towards more productive life situations, and be able to build self-awareness as a perfect human being, and be able to overcome psychological problems that interfere with the development of his soul.

\section{METHOD}

This research is an experimental research, while the type of experiment used is a type of "pretest-posttest control group design experiment", which is an experiment that compares an effect on an experimental group that will be treated with a control group that is not subject to the dependent variable. The population and sample in this study are prisoners in Class II A's Prison in Purwokerto who have served two-thirds of their sentence or before their release.

Data in 2020, the number of prisoners who have served two-thirds of the sentence or who will be free as many as 40 people. In addition, the data in this study were obtained from prison guidance officers, who in this case were officers who provided guidance to clients or prisoners on a daily basis. Based on the consideration of the prison officer and in accordance with the criteria set by the researchers namely prisoners who have high anxiety and low resilience obtained 20 study samples. Furthermore, for the sake of the sample experiments the researchers grouped them into two groups namely as a control and experimental group. Each group consists of 10 prisoners. Data collection techniques using non-test assessment techniques in the form of instruments. The method of data analysis uses average difference testing using parametric test in the form of One sample-t Within 9 Subjects and paired sample t-test (Santoso, 2004: 56). However, if the data are not normally distributed, the average difference test uses a nonparametric test in the form of the Wilcoxon Signed Ranks Test.

\section{RESULT}

The results of a descriptive analysis of prisoners' resilience before release in Class II A's Prison in Purwokerto was carried out to see the description of resilience of prisoners before release at Lapok Class II A Prison before being given cognitive-behavioral counseling with cognitive restructuring techniques. Descriptive description of prisoner resilience before release is presented in table 1.

\begin{tabular}{|c|c|c|c|c|c|c|}
\hline GROUP & N & Minimum & Maximum & Mean & Std. Deviation & P value \\
\hline Control & 10 & 89,00 & 114,00 & 99,0000 & 6,99 & \multirow{2}{*}{0,215} \\
\hline Experimen & 10 & 74,00 & 118,00 & 103,6000 & 15,03 & \\
\hline
\end{tabular}

Tabel 1:-Descriptive Statistic

Table 1 explained the results of the analysis show that prior to cognitive-behavioral counseling with cognitive restructuring techniques, prisoners' resilience in the control and experimental groups did not show any significant difference. Result showed in the control group, the total score of the answers respondents to questions related to resilience of prisoners have the lowest value of 89 and the highest of 114 with an average of 99 and a standard deviation of 6.99, then in the experimental class, the lowest score of respondents' answers to questions related to resilience of convicts is free has the lowest value 74 and the highest is 118 with an average of 103.6 and a standard deviation of 15.03 . The independent $t$ test which produces a $\mathrm{p}$ value of 0.215 , which means hadnot a different average value of prisoners scores in the control and experimental groups. 
In this study, prisoner resilience scores are categorized into 3 categories, namely low resilience $(X \leq 72)$, moderate resilience $(72 \leq X \leq 100)$ and high resilience $(X \geq 100)$, the following is the percentage of respondents in the control and experimental groups based on the category of respondent resilience level presented in table 2.

\begin{tabular}{|c|c|c|c|c|}
\hline \multirow{2}{*}{ Resiliensi } & \multicolumn{2}{|c|}{ Control Group } & \multicolumn{2}{|c|}{ Experimen Group } \\
\cline { 2 - 5 } & $\mathrm{f}$ & $\%$ & $\mathrm{f}$ & 0 \\
\hline Low $(\mathrm{X} \leq 72)$ & 0 & $0 \%$ & 4 & $0 \%$ \\
\hline Medium $(72 \leq \mathrm{X} \leq 100)$ & 5 & $50 \%$ & 6 & $60 \%$ \\
\hline High $(\mathrm{X} \geq 100)$ & 5 & $50 \%$ & $60 \%$ \\
\hline
\end{tabular}

Table 2:- Level of Resilience of Prisoners Before Counseling

Table 2 showed the 10 respondents in the control group $50 \%$ of whom had a level of resilience in the medium category and the remaining $50 \%$ had a high level of resilience, in line with the results in the control group, the analysis results in the above table also showed that in the experimental class, before prisoners are given counseling, the level of resilience of prisoners also tends to be high, $60 \%$ of the prisoners in the experimental class have a high level of resilience and the remaining $40 \%$ have a moderate level of resilience. This shows that before being given CBT counseling, the level of resilience of prisoners was free in Class II A's Prison in Purwokerto both in the control and experimental classes tended to be high. An illustration of the level of prisoners' resilience is illustrated in the following figure.

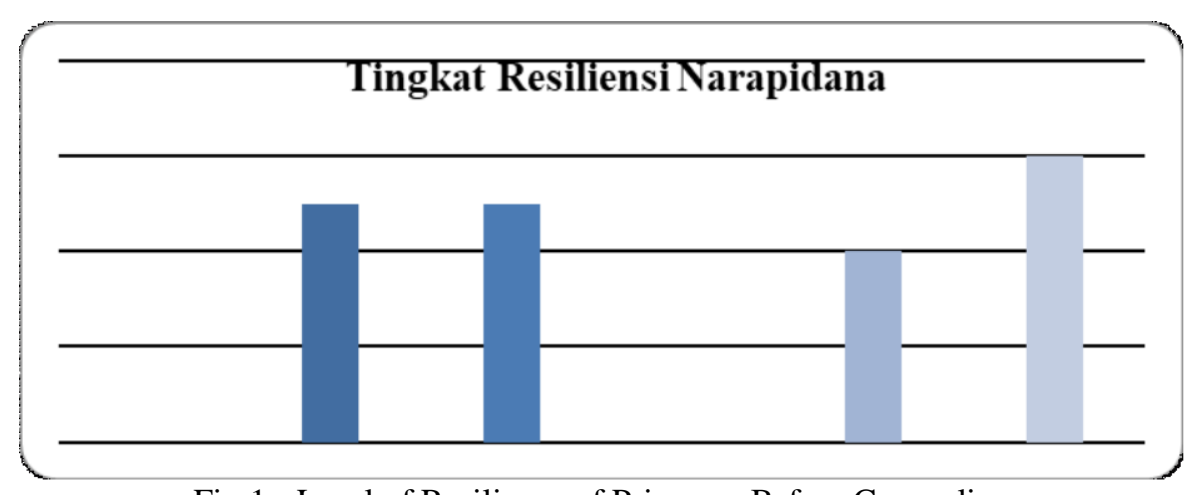

Fig 1:- Level of Resilience of Prisoners Before Counseling

After grouping for the level of resilience, counseling is done with Cognitive Behavior Therapy (CBT). One-sample T Test (of the Pre-Test and Post-Test values of experimental class are presented in Table 3 below.

\begin{tabular}{|c|c|c|c|c|c|c|}
\hline & \multicolumn{6}{|c|}{ Test Value $=20$} \\
\hline & \multirow{2}{*}{$\mathrm{t}$} & \multirow{2}{*}{ df } & \multirow{2}{*}{ Sig. (2-tailed) } & \multirow{2}{*}{ Mean Difference } & \multicolumn{2}{|c|}{$\begin{array}{l}95 \% \text { Confidence Interval of the } \\
\text { Difference }\end{array}$} \\
\hline & & & & & Lower & Upper \\
\hline Pre Test Eksperimen & $-870,967$ & 18 & 0,000 & $-28,50345$ & $-28,5705$ & $-28,4364$ \\
\hline Post Test Eksperimen & $-4327,266$ & 18 & 0,000 & $-28,07356$ & $-28,0869$ & $-28,0603$ \\
\hline
\end{tabular}

Table 3:- One -sample T Test (Within-Subject)

Based on Table 3 shows the significance value for the experimental class pre-test value of $0,000<0.05$ and the significance value for the post-test value of the experimental class $0,000<0.005$. It showed of the experimental class proved to be a significant difference with the number of achievements of 20 prisoners. For that, the effectiveness of the effectiveness of CBT in increasing prisoners' resilience can be seen in Table 4 . 
ISSN No:-2456-2165

\begin{tabular}{|c|c|c|c|c|c|c|c|c|}
\hline \multirow{3}{*}{ Information } & \multicolumn{5}{|c|}{ Paired Differences } & \multirow{3}{*}{$\mathrm{t}$} & \multirow{3}{*}{$\mathrm{df}$} & \multirow{3}{*}{$\begin{array}{l}\text { Sig. (2- } \\
\text { tailed) }\end{array}$} \\
\hline & \multirow[t]{2}{*}{ Mean } & \multirow[t]{2}{*}{ Std. Deviation } & \multirow[t]{2}{*}{ Std. Error Mean } & \multicolumn{2}{|c|}{$\begin{array}{c}95 \% \text { Confidence Interval of } \\
\text { the Difference }\end{array}$} & & & \\
\hline & & & & Lower & Upper & & & \\
\hline $\begin{array}{cc}\text { Pair } 1 & \text { Post Test } \\
& \text { Eksperimen } \\
& \text { - Pre Test } \\
& \text { Eksperimen }\end{array}$ & 0,42989 & 0,17397 & 0,03231 & 0,36371 & 0,49606 & 13,307 & 18 &, 000 \\
\hline
\end{tabular}

Table 4:- Paired Sample Test

Table 4 showed that the results of the effectiveness of CBT test in increasing prisoners' resilience mean that there is a difference in the tendency for more confidence before using CBT techniques and after CBT techniques. If the significance of $\mathrm{t}$ arithmetic $<0.05$ then the treatment is effective increased prisoners' resilience. Based on the results of tests on experimental classes prove that CBT techniques are effective in increasing prisoners' resilience.

\section{DISCUSS}

\section{$>$ Resilience' Level of Prison Inmates Before Being Released In Class II A's Prison in Purwokerto}

Prisoner resilience adapted to severe incidents while in prison. The result showed the 10 inmates in the control group $50 \%$ of whom had a high level of resilience in the medium category and the remaining $50 \%$ had a high level of resilience, in line with the results in the control group, showing that in the experimental class, before inmates were given counseling, a prison resilience tends to be $60 \%$ of the prisoners in the experimental class have a high level of resilience and the remaining $40 \%$ have a moderate level of resilience. This shows that before being given CBT counseling, the level of resilience of prisoners before being released in Class II A's Prison in Purwokerto both in the control and experimental classes was actually high.

Riza and Ike (2013) explained that prisoners who have high resilience are described as having plans that will be carried out after leaving prison. The plan includes starting a new life with family and community. In Corrections Institutions, he is able to undergo all his activities without being burdened. Resilience is an important thing that must exist in an adult inmate, because with a resilient attitude, he will struggle to adapt, survive and rise from adversity. Resilient prisoners will gain knowledge, experience and skills that are used to live their lives back to the community.

In general, resilience increased from adversity that occurs in his life. People with positive resilience will find it easy to return to normalcy. In addition, people with positive resilience are able to manage emotions emotionally. Individuals have the right and the right to feel sad, angry, feel lost, hurt and depressed. The difference is, individuals do not allow such feelings to persist for long. Individuals quickly cut off uncomfortable and unhealthy feelings, and then help them grow into stronger people. Personal with high resilience will be able to get out of trouble quickly and not sink with feeling as victims of the environment or circumstances and be able to make decisions when in difficult situations. Resilience generally leads to positive adaptation patterns during or after facing difficulties or risks.

> The effectiveness of Cognitive Behavior Therapy (CBT) Techniques To Increase Prisoners' Resilience Before Being Released in Class II A's Prison in Purwokerto

Research showed that the hypothesis stating that the Cognitive Behavior Therapy (CBT) technique is effective for increasing the resilience of prisoners before being released in Class II A's Prison in Purwokerto can be accepted. The effectiveness of Cognitive Behavior Therapy (CBT) techniques performed can be seen from an increase in the resilience level of prisoners before being released after obtaining Cognitive Behavior Therapy (CBT) techniques. Based on the average value, it can be seen that the mean score of prisoners' resilience level during the pretest has increased at the post-test.

After getting CBT counseling, inmates can turn negative thoughts after being prisoners and thoughts that are more positive and rational. Prisoners who will be released are better able to explain their emotions and behavior, $m$ determine the right solution of the problem, the existence of confidence and confidence and be able to get new opportunities and challenges to live better after being released from detention.

The results of this study are in accordance with Cross (2015) which states that CBT helps individuals recognize negative thought forms and replace them with more accurate and positive ones, so that individuals have increasing resilience. CBT is also believed to help individuals to improve their competence, positive mindset and be able to adapt after leaving the field later. CBT is believed to help individuals identify and solve problems and use new strategies in managing the source of the problems they experience (Cross, 2015). Neenan (2009) also found that CBT not only helps individuals overcome the problems that they are facing, but also helps build new views about themselves, namely as individuals who are strong and able to overcome existing challenges, find happiness in life, and determine important goals that are will be achieved. Or in other words, help individuals build resilience capabilities. 
Resilience generally leads to positive adaptation patterns during or after facing difficulties or risks. Increasing resilience is an important task because it can provide experience for humans in facing life's challenges and difficulties. By increasing resilience, humans can develop life skills such as how to communicate, realistic abilities in making life plans and be able to take the right steps for their lives (Rojas, 2015).

Positive outcomes related to resilience are alleviating the negative effects of stress, improvement in adaptation, and the development of effective coping skills to deal with change and difficulties. Therefore, resilience adaptive and to overcome similar situations that are detrimental in the future (Keye and Pidgeon, 2013).

\section{CONCLUTION AND RECOMENDATION}

This research concluded that among others 1) the resilience's level of prisoners before being released in Class II A's Prison in Purwokerto both in the control and experimental classes was actually high; 2) Cognitive Behavior Therapy (CBT) techniques are effective in increasing the resilience of prisoners before being released in Class II A's Prison in Purwokerto can be accepted. Based on the average value, it can be seen that the mean score of prisoners' resilience level during the pre-test has increased at the post-test.

Suggestions that can be proposed include 1) The results of this study indicate that CBT is proven to increase the resilience of prisoners to explain freely. Every prisoner and before release will have to have high resilience, the prison should always provide counseling to every prisoner to be released, this counseling in addition to increasing prisoners' resilience so that they will be better prepared in facing future problems; 2) For further research, further research is expected to be carried out using other counseling techniques, some previous studies have provided various forms of counseling but are used by respondents not prisoners, so that for further research is expected to be able to use other counseling techniques.

\section{REFERENCES}

[1]. AL-Qarni, A.2006. La Thzan Jakarta: Qisthi Press

[2]. Connor, K.M and Davidson, J.R.T.2003. Development of a New Resilience Scale: The Connor Davidson Resilience Scale. CD-RISC. Depression and Anxiety. Retrievd From http://onlinelibrary.wiley.com

[3]. Dong, F. Khan.A. Ablah.E and Ph. D. 2013. Modified CD-RISC: Including Previously Unaccounted for Resilience Variables. Kansas Journal of Medicene, 61

[4]. Henning, V. 2011. Depression, anxiety, and history of substance abuse among Norwegian prisoners in preventive detention: Reasons to worry? Open Acces Article. Dept. of Psychiatric $R$ and D, Akershus University Hospital,
[5]. Hutnik, N., Smith, P., and Koch, T. 2016 . Using cognitive behaviour therapy to explore resilience in the life-stories of 16 UK centenarians. https://doi.org/10.1002/nop2.44

[6]. Kartono, K. 2011. Patologi Sosial Jilid 1. Jakarta: PT. RajaGrafindo Persada.

[7]. Keye, M. D., \& Pidgeon, A. M. 2013 . An Investigation of the relationship between resilience, mindfulness, and academic self-Efficacy. Open Journal of Social Sciences, 16 , 1-4. https://doi.org/10.4236/ jss.2013.16001

[8]. Masten, A. S. 2007 . Resilience in developing systems: Progress and promise as the fourth waves rises. 921-930. https://doi.org/10.1017/S0954579407000442

[9]. Müller-fabian, A. 2015 . Main characteristics of inmate mothers - emphasized on their psycho-socioeducational status. Procedia - Social and Behavioral Sciences, 209 July , 344-350. https://doi.org/10.1016/j.sbspro.2015.11.247

[10]. Neenan, Michael \& Dryden, Windy. 2006 . Rational Emotif Behavioral Therapy in a nutshell. London: Sage Publications

[11]. Norte, C. E., Souza, G. G. L., Pedrozo, A. L., Mendonça-de-souza, A. C. F., Figueira, I., Volchan, E., \& Ventura, P. R. 2010 . Impact of cognitivebehavior therapy on resilience-related neurobiological factors. 4-6.

[12]. Octaryani, M., Baidun, A., \& Jakarta, H. 2017 . Uji validitas konstruk resiliensi. VI 1, 43-52.

[13]. Padesky, C. A., \& Mooney, K. A. 2012 . StrengthsBased Cognitive - Behavioural Therapy: A Four-Step Model to Build Resilience. 290 May , 283-290. https://doi.org/10.1002/cpp.1795

[14]. Pratiwi, L. R. 2018 . Terapi Realitas Sebagai Sarana Meningkatkan Resiliensi Pada Penyandang Tuna Daksa. Intuisi Jurnal Psikologi Ilmiah, 101.

[15]. Revich, K. and S. A. 2002 . The Resilience Factor. New York: Broadway Books.

[16]. Riza M. Ike H. 2013 . Resiliensi pada Narapidana Laki-laki di Lapas Kelas I Madaeng. Jurnal Psikologi Kepribadian Dan Sosial, 21.

[17]. Rojas, F. L. 2015 . Factors affecting academic resilience in middle school students: A case study. Gist Education And Learningresearch Journal, 1111 , 63-78.

[18]. Shienkfield, A. 2010 . Prisoners Prerelease Anxiety Levels. The Deakin University Australia.

[19]. Songprakun, W., \& Mc.Cann, T. 2012 . Effectiveness of a self-help manual on the promotion of resilience in individuals with depression in Thailand: A randomised controlled trial. BioMed Central Psychiatry 1212 , 1-10, doi10.86/1471-244X-12-12

[20]. Suwarjo. 2008 . Modul Pengembangan Resiliensi. Yogyakarta: Jurusan Psikologi Pendidikan dan Bimbingan FIP UNY.

[21]. Taylr, S.E/2006. Health Psychology. (6th Ed). Singapore: Mc.Graw Hill Book Company 
[22]. Utami, C. T. dan H., \& Avin, F. 2017 . Self-Efficacy dan Resiliensi: Sebuah Tinjauan Meta-Analisis. Buletin Psikologi, 251 , 213-227. Retrieved from https://search.proquest.com/docview/196305681?acco untid $=189284$

[23]. Utari, D.I., Fitria, N \& Rafiyah, I. 2011 . Gambaran tingkat Kecemasan pada Narapidana Wanita Menjelang Bebas di Lembaga Pemasyarakatan Kelas II A Bandung. Jurnal Universitas Padjadjaran.

[24]. Yuniardi, M.S. 2009. Analisis Potensi Resiliensi Korban Lumpur Panas Lapindo: Tinjauan pada Tiap Tahap Perkembangan. Jurnal Psikologi, 4.2 